\title{
Trickle-Down Economics; Is it Valid in Egypt?
}

\author{
Abdelmonem Lotfy Mohamed \\ Assistant Professor of Economics and Public Finance \\ Faculty of Economic Studies and Political Science, \\ Beni-Suef University, Beni-Suef, Egypt;
}

\begin{abstract}
Several research papers have been conducted to investigate whether the trickle-down effect is valid in countries such as India, Switzerland, Indonesia, and others. This paper tries to get an answer to the same question for Egypt. The paper found no evidence to the trickle-down economics for the Poor in Egypt. Econometric analysis assured that high economic growth rates in Egypt were accompanied with increase in poverty rates. Decline in poverty rates in Egypt, which rarely to appear, that the Egyptian society witnessed during 1990s were largely attributed to government anti-poverty measures implemented during the Economic Reform and Structural Adjustment Program (ERSAP). These measures were mitigation policies related to Economic Reform program that the Egyptian government executed starting 1991 under IMF and World Bank supervision. Finally, the paper concluded that it is better to the Egyptian government to change its dependence on trickle-down theory of economic development into bottom-up economic development approach.
\end{abstract}

Keywords: Trickle-down effect; Poverty in Egypt; Economic growth; Capital formation, ERSAP.

\section{INTRODUCTION}

Researchers like Ravallion and Datt (2002), Mellor (1999), Dollar and Kraay (2002), Fan et al. (2000) and the World Bank (1995), have concluded that the increase in economic growth rates cause a reduction in the incidence of poverty. On the other hand, Fishlow (1995) refuted this claim where he found that the rise of economic growth rates did not achieve decrease in poverty rates in Latin America. This was because the existence of extreme inequality, as Fishlow (1995) concluded.

In the Egyptian context, it is noted that since 1960s, Egyptian governments have directly intervened to help the poor and reduce the incidence of poverty. On the same road, since 2014, Egypt concentrated to reduce poverty through stimulating economic growth. This is done through expanding government spending on infrastructure development, such as roads, New Suez Canal project, and establishing a new administrative capital; all of which have indirect relationship with both economic growth and poverty reduction. However, the literature (Ravallion and Datt, 2002) found that there is an insignificant correlation between the two variables; government spending on development and poverty reduction. Moreover, (Dollar and Kraay, 2002) found a negative correlation between these two variables in a cross country study. In this context, papers that have researched to investigate the effect of government direct intervention have found that a positive effect on poverty reduction has been made by government expenditure (Fan et al, 2000).

On the light of this debate in the literature, the paper tries to find out whether the trickle-down effect has taken place in Egypt or not. The economic analysis will be extended to include the impact of capital formation. The paper will test the relationship between capital formation, economic growth, and poverty level in the Egyptian economy. 
The paper is planned as follows. Second section discusses the problems occur when investigating whether the trickle-down effect has, or has not, existed in Egypt. Third section tests the empirical relationship between changes in poverty rate in Egypt and either changes in economic growth or capital formation. Finally, in section 4, the paper illustrates an explanation to the research results.

\section{THE RELATIONSHIP BETWEEN POVERTY, ECONOMIC GROWTH, AND CAPITAL FORMATION \\ Problems with investigating trickle-down effect in Egypt}

Evaluating the trickle-down effect in Egypt is considered a complicated issue since there is no single era where the Egyptian government intervene to help the poor in the last fifty years. As a result, to test for the existence of trickle-down effect in Egypt, it is needed to choose a period where the Egyptian government did not implement direct interventions to assist the poor. Therefore, the optimal era to be chosen for testing such an effect is the start of Economic Reform and Structural Adjustment Program (ERSAP) that the Egyptian government initiated on 1991. It was the era where the Egyptian government began liberalizing the Egyptian economy and follow the market oriented economic system. Starting 1991, the Egyptian government economic philosophy was based on expanding the private sector role in economic activities in order to create greater job opportunities that would be a vehicle to poverty reduction. Consequently, several economic policies and regulations have been introduced to enhance business climate and investment levels in the Egyptian economy. Capital accumulation was considered the main engine for economic growth and jobs creation. Therefore, to obtain a complete vision about the trickle-down effect in Egypt, it is better to investigate not only the effect of economic growth on poverty but also to examine the relationship between capital formation and poverty. The study is considering capital formation as a proxy for capital accumulation.

\section{Directions for poverty rates and economic growth rates in Egypt}

During 1990's and the first decade of the Third Millennium, the Egyptian government continued following the market oriented economic system through privatization, liberalizing interest rates and exchange rate, and attracting foreign investments to promote capital accumulation in the Egyptian economy. It seemed that the different Egyptian governments during President Mubarak role agreed to apply the trickle-down economics approach, especially during Nazif government that was appointed on July 2004 until the first revolution on $25^{\text {th }}$ January 2011. Nazif government was considered the extremist Egyptian government to apply the trickle-down economics approach since it reduced taxes on high income groups by 50 percent through the new Income Tax Law ratified in 2005. In addition, several businessmen were appointed as Ministers in the Egyptian government and in high positions in the Egyptian Parliament, a phenomena that was named as "Capital and Authority Marriage". Consequently, those businessmen policymakers introduced policies and laws that gave great incentives to private sector and high income groups on the hope to rise investments, economic growth, and create more jobs to eradicate poverty. The government succeeded to increase both GDP and GDP per capita growth rates to become 7.2 and 5.3 percent in 2008 respectively. However, the percentage of the Egyptian population lying under the poverty line climbed sharply during this decade where it was 17.1 percent in 2003, directly before Nazif government, and climbed to 25.2 percent in 2011. As a result, the first revolution took place with loud calls towards economic and social justice.

Through the era between the two revolutions 2011 - 2013 and because of political troubles, poverty rates continued to rise where it reached to 26.3 percent in 2013 and 27 percent in 2014. On the other hand, GDP growth rates also decreased to become only 2 percent on 
average during the fiscal years 2010/2011 - 2013/2014. Moreover, GDP per capita growth rates were negative during these three fiscal years achieving an average of -0.14 percent.

In 2014, the Egyptian government initiated another economic reform program with the help of the IMF and World Bank technical and financial assistants. The IMF Executive Board approved this reform program and agreed to lend Egypt \$US 12 billion support under the IMF's Extended Fund Facility (EFF). The recent Egyptian economic reform program aimed at restoring the economic stability of Egypt and paving the way for higher long-term growth. The government has taken several reform policies that are bold but necessary while trying to protect the poor. The reform program was based on restructuring subsidies, especially with regard to eliminating energy subsidies, and introducing a new Value Added Tax law in order to restoring macroeconomic stability and sustainable public finances. In addition, the Central Bank of Egypt liberalized the foreign exchange market through crucial devaluation for the Egyptian Pound; therefore, the Egyptian foreign exchange market got rid of foreign currency shortages. Also, monetary policy focused on reducing inflation rate, which reached to a historical record exceeding 35 percent by July 2017, through rising interest rates to absorb liquidity. Moreover, wide-ranging structural reforms have been taken to enhance business environment in order to boost economic growth and create job opportunities. For example, a new Investment Law was introduced by the end of 2017 granting a lot of incentives to all types of investors. In addition, several measures were approved to facilitate doing business such as less red tape in industrial licensing, and easier access to finance for small and medium-sized enterprises.

On the other hand, the Egyptian government is trying to shield the poor from the adverse effects of these severe economic changes. As a result, the government reallocated part of the reduced energy subsidies towards social public spending on health and education. In addition, programs for targeted cash transfers were initiated to help the poor overcome sharp increases in prices.

Consequently, recent economic reforms taken by the current Egyptian government reflect that the same philosophy of trickle-down economics is there. Therefore, it is necessary to investigate whether it is a suitable philosophy for the Egyptian economy or not.

\section{Data for the three variables}

Data on GDP and GDP per capita growth rates are taken from the World Bank's web site1. While data for poverty rates in Egypt were taken from the Central Agency for Public Mobility and Statistics (CAPMAS), the Household Income, Expenditure, and Consumption Survey (HIEC) for the years from 1990/1991 until 2015/2016. The poverty rate for 2016 that reached to 39.8 percent was estimated by the author using the income classes presented in the HIEC for the year 2015/2016 and the statistic that CAPMAS announced about Egypt's poverty line to increase to 800 EGP monthly per person. As a result of the economic decisions taken by the Egyptian government during 2016, inflation rate reached to a historical record where it rose to 35.2 percent in July 2017. Consequently, these drastic economic conditions have its negative implications on both poverty line and the incidence poverty rate in Egypt. The study is using the methodology of head-count ratio (HCR) to measure poverty rate in Egypt. The HCR is the proportion of the population lying below the poverty line. Since the study aims to investigate whether the percentage of the Egyptian people living below the poverty line has decreased

\footnotetext{
1 The link for GDP rates is: https://data.worldbank.org/indicator/NY.GDP.MKTP.KD.ZG?locations=EG.

The link for Capital Formation is: https://data.worldbank.org/indicator/NE.GDI.TOTL.ZS?locations=EG-ET-SS-SD.
} 
over time or not; using HCR is the optimal choice to estimate the relationship between economic growth and poverty rate in Egypt.

It is noted that CAPMAS conducts HIEC every five years since 1995. Consequently, there are several gaps in the poverty rate data. To overcome this problem, the study will interpolate these missed data.

The study is conducted using annual data through the period 1987 to 2016 with 30 observations for each variable. The study chose to start the analysis from 1987, four years before the start of the first economic reform program implemented in Egypt (ERSAP), in order to examine the impact of ERSAP initiated in 1991 on poverty rate in the Egyptian society. The following Figure 1 illustrates the trend of change for the three variables; the poverty rate, the GDP growth rate, and the capital formation.

\section{Figure I.1: Poverty Rate in Egypt}

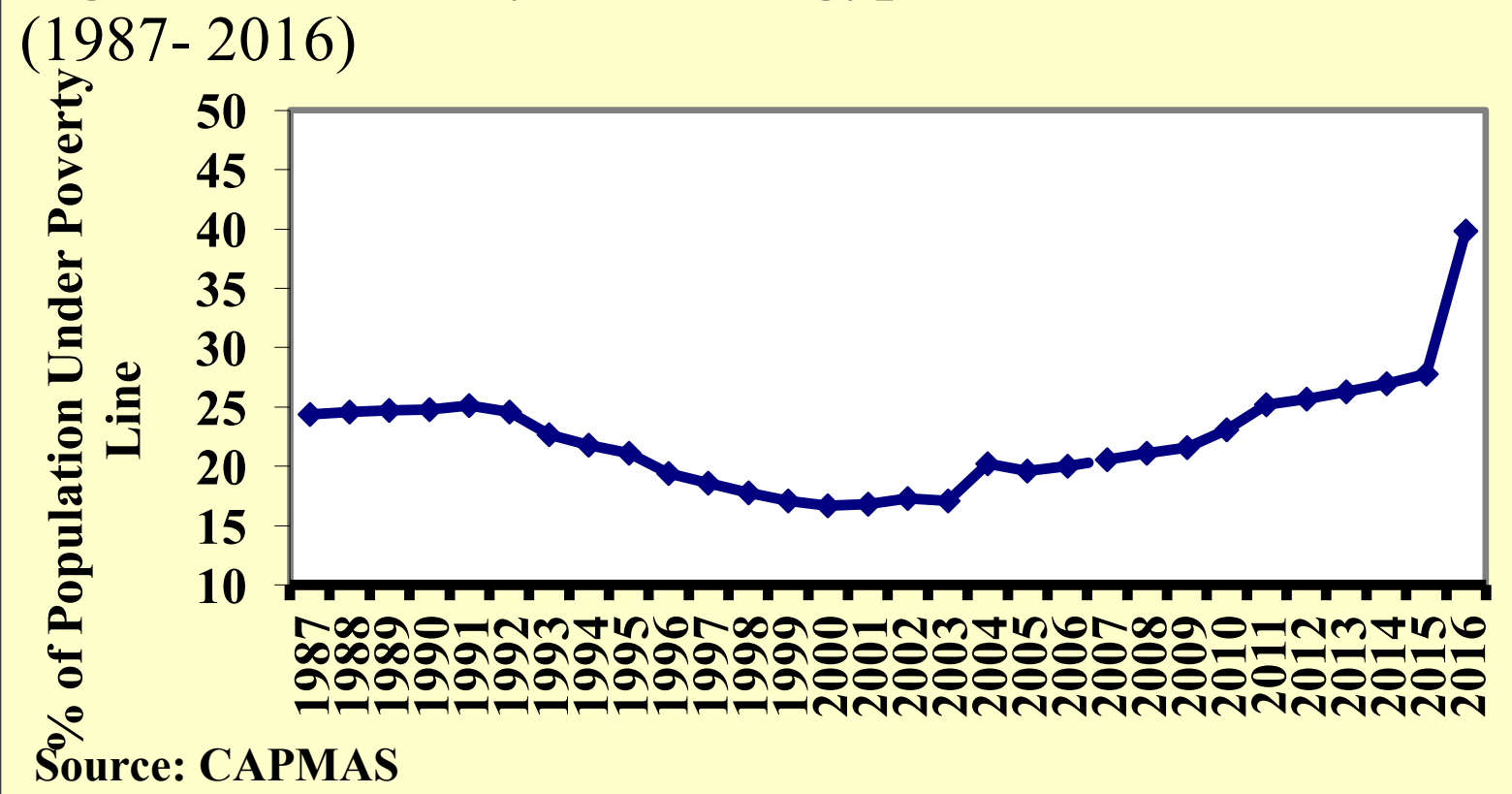




\section{Figure I.2: GDP Growth Rates in Egypt (1987-2016)

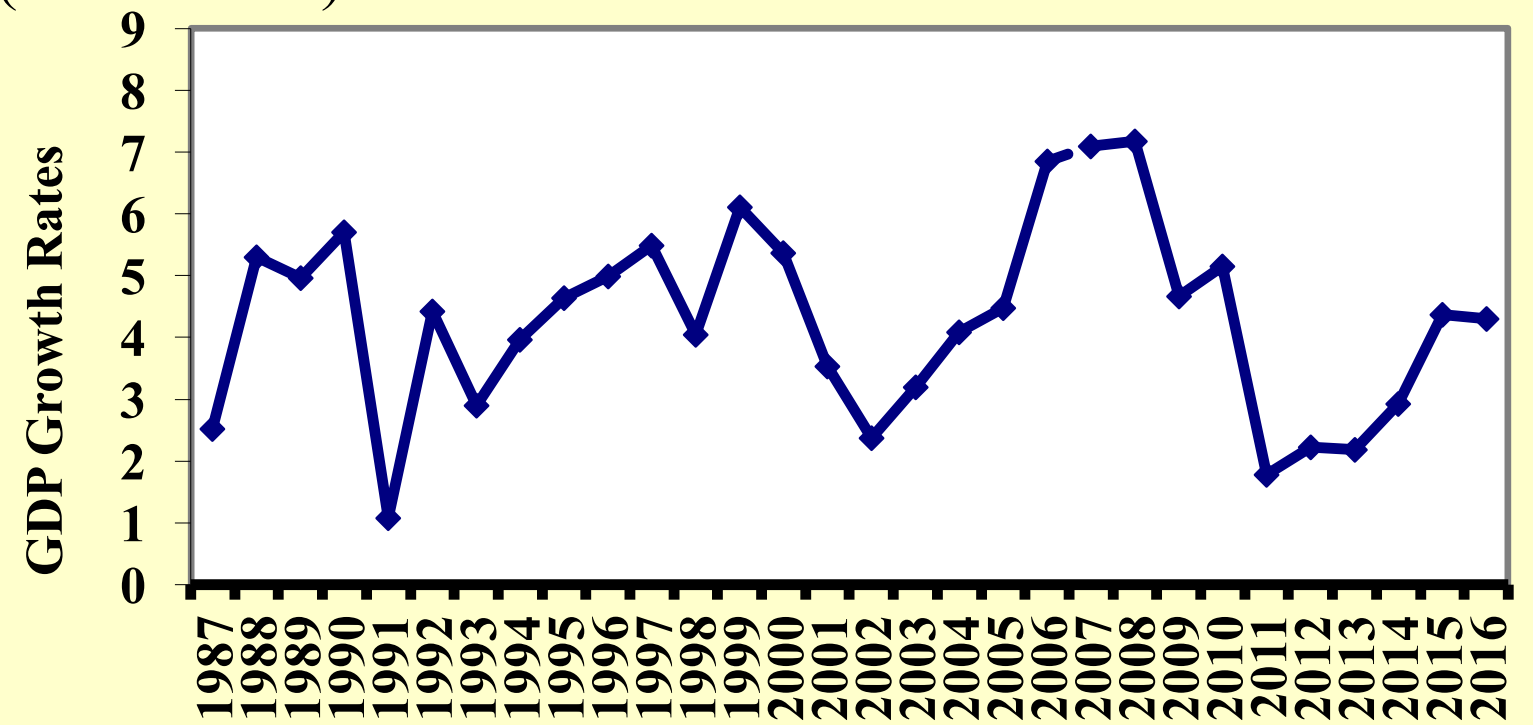

Source: World Bank

\section{Figure I.3: Capital Formation Rates in} Egypt

(1987-2016)

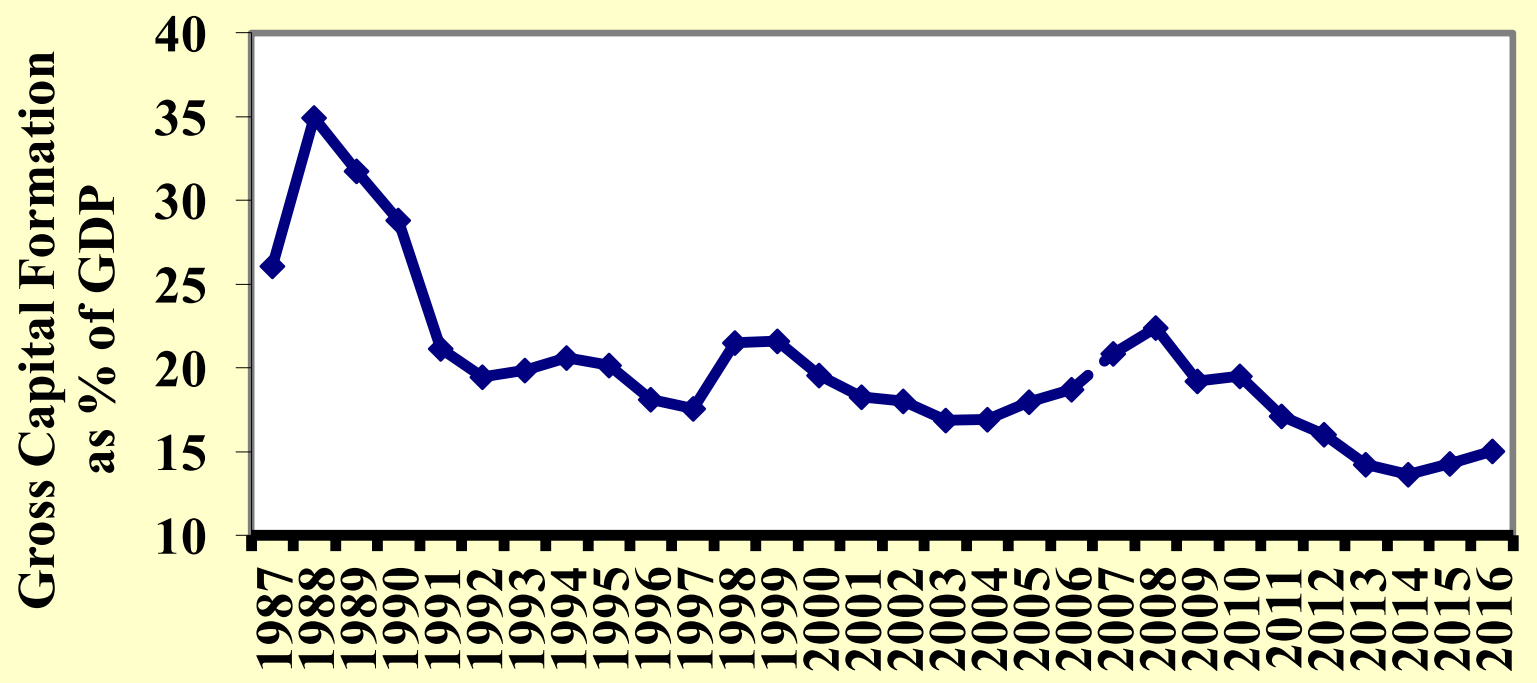

\section{Source: World Bank}

According to Figure 1, it seems that poverty rate was stable during the period 1987 until 1991. Then it started to decline after initiating ERSAP in 1991 until 2003. It began to rise since 2004 in an accelerated base until 2015. After 2015, poverty rate increased sharply because of the recent economic reforms.

With regard to GDP growth rates, it was volatile during the period 1987 until 2008. It reached to its peak in 2008 with 7.2 percent. Starting 2009, it declined and reached to its minimum in 
2011 with 1.78 percent. After the first revolution, growth rates have increased gradually reaching 4.3 in 2016.

For gross capital formation as percentage of GDP, it increased to its peak reaching 35 percent of GDP in 1988. Then it has declined gradually to reach 15 percent in 2016, less than half of its level in 1988. This sharp decline for this variable reflects crucial deterioration in public investments during the last 25 years in the Egyptian economy.

\section{EXPERIMENTS AND ANALYSIS FOR INVESTIGATING THE RELATIONSHIP BETWEEN GROWTH, CAPITAL FORMATION, AND POVERTY RATE}

\section{Augmented Dickey-Fuller (ADF) unit root test results}

To investigate the relationship, first, it is needed to test the stationarity of the time series of the three variables included in the model. The reason behind this is that many time series are nonstationary and needed to determine its degree of integration. To do so, the Augmented Dickey Fuller (ADF) test provided in (Dickey and Fuller, 1981) is conducted. The ADF test can be represented as follows;

$$
\Delta \mathrm{Yt}=\Phi \cdot \mathrm{Yt}-1+\mathrm{k} \sum_{\mathrm{i}=1} \Phi \mathrm{i} \cdot \Delta \mathrm{Yt}-\mathrm{i}+\varepsilon \mathrm{t}(1)
$$

Where $\mathrm{k}$ represents the number for lags for $\Delta \mathrm{Yt}$-i that has to be in a level which saves the degrees of freedom and allow for the presence of autocorrelation in $\varepsilon t$.

In this context, the autoregressive coefficient $\alpha 0$ is as follows;

$$
\mathrm{Yt}=\alpha 0 \mathrm{Yt}-1+\varepsilon \mathrm{t}
$$

It can be adjusted to;

$$
\Delta \mathrm{Yt}=(\alpha 0-1) \mathrm{Yt}-1+\varepsilon \mathrm{t}
$$

If $\alpha 0$ is less than 1 , then Yt is integrated of order zero. If not, then we test;

$$
\Delta \Delta \mathrm{Yt}=(\alpha \mathrm{t}-1) \Delta \mathrm{Yt}-1+\varepsilon \mathrm{t}
$$

If $\alpha 1$ is less than 1 , then Yt is integrated of order one. This process is continued until stationarity is reached.

Using E-views 7, the study found that there is an evidence of a unit root in all the three variables which indicates that the three variables are all non-stationary. Table 1 presents results for ADF tests where poverty rate is (POVR), GDP growth rate is (GDPGR), and capital formation is (CF). 
Table 1. Augmented Dickey-Fuller (ADF) unit root test results

\begin{tabular}{|c|c|c|c|}
\hline ADF (With trend) & POVR & GDPGR & CF \\
\hline In Levels & -2.13 & -3.14 & -1.09 \\
\hline In First Differences & -2.72 & -4.58 & -2.81 \\
\hline $\begin{array}{c}\text { In Second } \\
\text { Differences** }\end{array}$ & -6.33 & -6.41 & -4.25 \\
\hline $\begin{array}{c}\text { Critical Values 5\% } \\
\text { level }\end{array}$ & -3.5312 & -3.5312 & -3.5312 \\
\hline Integration Level & $\mathrm{I}(2)$ & $\mathrm{I}(2)$ & $\mathrm{I}(2)$ \\
\hline
\end{tabular}

** Significant at $5 \%$ level

Source: Author own estimations using the specified data series.

The study found that the three variables are integrated of order two I(2). Consequently, it follows that co-integration among these variables has to be tested.

\section{Co-integration Test and Johansen Technique Results}

In case of a multivariate co-integration test, Johansen's co-integration method (Johansen, 1988 ) is highly recommended to use. The model of these three variables support Johansen's vector auto-regression (VAR) model in second differences since the three variables are I(2). This technique examines two hypothesis. The null hypothesis of no co-integration versus the alternative one stating co-integration. The test yields two likelihood ratio statistics related to the number of co-integration vectors, the maximum eigenvalue and the trace statistics. This framework is used to test the long-run relationships between poverty rate, GDP growth rate, and capital formation in Egypt. The Akaike Information Criterion (AIC) is used to determine the number of lags used in the VAR model and it selected one lag to be the optimal lag for all variables.

The results, presented in Table 2 , show that there is an equilibrium relationship between the three variables in the long-run. The null hypothesis $\mathrm{R}=0$ is rejected which means the existence of long-run relationship between poverty rate, GDP growth rate, and capital formation in Egypt.

Table 2. Results for Co-integration Test between POVR, GDPGR, and CF.

\begin{tabular}{|c|c|c|c|}
\hline No. of CEs & Eigenvalue & Likelihood Ratio & 5\% Critical Value \\
\hline $\mathrm{R}=0$ & 0.435 & $35.126^{*}$ & 29.97 \\
\hline $\mathrm{R}=1$ & 0.054 & 4.85 & 15.86 \\
\hline $\mathrm{R}=2$ & 0.012 & 0.683 & 3.86 \\
\hline
\end{tabular}

* Long-run trace test indicates 1 co-integration equation Significant at $5 \%$ level.

Source: Author own estimations using the specified data series.

The following equation provides the long-run relationship between variables;

$$
\text { POVR }=11.2+0.9 \text { GDPGR }-0.7 \mathrm{CF}
$$

$$
(-2.97) \quad(-1.58) \quad(1.486)
$$

It shows that poverty rate (POVR) is positively impacted by changes in GDP growth rate (GDPGR) and negatively affected by capital formation rate (CF). According to this long-run equation, a 1 percent increase GDP growth rate leads to 0.9 percent increase in poverty rate in the Egyptian economy; On the other hand, a 1 percent increase in capital formation causes a 
decline in poverty rate by 0.7 percent in the long-run, other things hold equal. These two coefficients are significant; R-square and R-square adjusted are 0.63 and 0.57 respectively.

In order to describe a short-run interactions for this model of three variables, the Vector Error Correction Model (VECM) is used to derive the short-run model from the long-run one. This enable the study to estimate the poverty rate response to and changes (or shocks) in both GDP growth rate and investment level in the Egyptian economy. Table 3 illustrates VECM estimates;

Table 3. VECM estimates between POVR, GDPGR, and CF.

\begin{tabular}{|c|c|c|c|}
\hline & POVR & GDPGR & $\mathbf{C F}$ \\
\hline $\begin{array}{c}\text { Error correction co-integration } \\
\text { equation }\end{array}$ & $-0.66(-5.263)^{*}$ & $-0.15(-1.35)$ & $0.21(1.198)$ \\
\hline$\Delta \Delta \mathrm{POVR}(-2)$ & $0.054(0.385)$ & $0.062(0.399)$ & $0.28(1.369)$ \\
\hline$\Delta \Delta \mathrm{GDPGR}(-2)$ & $0.43(2.799)$ & $-0.34(-1.98)$ & $\begin{array}{r}0.086 \\
(0.458) \\
\end{array}$ \\
\hline$\Delta \Delta \mathrm{CF}(-2)$ & $-0.21(0.458)$ & $-0.18(-1.444)$ & $-0.19(-2.02)$ \\
\hline $\mathrm{C}$ & $-0.56(-2.56)$ & & \\
\hline R-square & 0.63 & & \\
\hline Adj. R-square & 0.57 & & \\
\hline F-statistic & 8.233 & 2.895 & 1.874 \\
\hline Akaike Information Criteria & & -5.128 & \\
\hline
\end{tabular}

* t-values in parentheses.

Source: Author own estimations using the specified data series.

In the short-run, results in table 3 show that a 1 percent increase in GDP growth rate raises poverty rate by 0.43 percent. Also, the error correction coefficient is negative and significant = -0.66 which means that $66 \%$ of the deviations from the long-run equilibrium will be reversed in the coming years. It is an indication to a so fast adjustment which can only happen because of government (or any external institution) interventions to help the poor and alleviate poverty. For capital formation, results show that 1 percent increase in capital formation as a percentage of GDP decrease poverty rate by 0.21 percent. Also, coefficients are significant; Rsquare and R-square adjusted are 0.63 and 0.57 respectively. These results assure the long-run analysis.

The above analysis provides that the trickle-down economic growth theory has not been proven to be valid in Egypt. It seems that economic growth in the Egyptian economy is biased to the rich segmentations in the Egyptian society. Moreover, the capital formation as a percent of GDP have been declining across the last 30 years which makes the situation to reach the worst. Therefore, declines in poverty rates that appeared separately during the last 30 years are due to government intervention to eradicate poverty. However, the most important question that needs an answer is, in a labor-surplus economy with low levels of wages, why did trickle-down economics is not valid in Egypt? In the following section the study will try to explain answering this important question.

\section{Explaining Why the Trickle-down Economics is Not Valid in Egypt}

The study attributes why the trickle-down effect did not take place in Egypt due to high inequality that have been increasing across the last 30 years in the Egyptian society. High inequality in distributing income, jobs, subsidies, and social benefits is attenuating the impact of growth on poverty reduction in the Egyptian economy (Marotta, Yemtsov, El-Laithy, AbouAli, Al-Shawarby, 2011). The rich is achieving economic gains more than the poor. As an example, the following table shows that the economic growth during 2005 to 2008 was biased against the poor in Egypt. The table 4 presents percentiles of the distribution. For example, the ratio of consumption between population at the $25^{\text {th }}$ percentile and population on the $10^{\text {th }}$ 
percentile (which is poorer) is presented as $\mathrm{p} 25 / \mathrm{p} 10$. The table illustrates a widening of distribution at the top, expressed by $\mathrm{p} 90 / \mathrm{p} 50$ and p75/p50, and at the bottom, expressed by p25/p10.

Table 4. Indices of Inequality for Consumption by Urban and Rural Areas during 2005-2008.

\begin{tabular}{|c|c|c|c|c|c|c|}
\hline & \multicolumn{2}{|c|}{$\begin{array}{l}\text { Lower Half of } \\
\text { the Distribution }\end{array}$} & \multicolumn{2}{|c|}{$\begin{array}{l}\text { Upper Half of } \\
\text { the Distribution }\end{array}$} & \multirow[b]{2}{*}{ P90/p10 } & \multirow[b]{2}{*}{ Gini } \\
\hline & P25/p10 & P50/p25 & P75/p50 & P90/p50 & & \\
\hline \multicolumn{7}{|l|}{ Total } \\
\hline 2005 & 1.26 & 1.33 & 1.36 & 1.95 & 3.27 & 28.67 \\
\hline 2008 & 1.32 & 1.33 & 1.38 & 1.98 & 3.48 & 30.46 \\
\hline \multicolumn{7}{|l|}{ Urban } \\
\hline 2005 & 1.33 & 1.41 & 1.38 & 2.04 & 3.84 & 30.23 \\
\hline 2008 & 1.33 & 1.37 & 1.42 & 2.13 & 3.87 & 32.34 \\
\hline \multicolumn{7}{|l|}{ Rural } \\
\hline 2005 & 1.23 & 1.27 & 1.26 & 1.56 & 2.42 & 20.43 \\
\hline 2008 & 1.29 & 1.31 & 1.28 & 1.59 & 2.68 & 21.99 \\
\hline
\end{tabular}

Source: Calculations are taken from (Marotta, Yemtsov, El-Laithy, Abou-Ali, Al-Shawarby, 2011) based on HIEC 2005-2008.

Moreover, even with regard to subsidies, the richest segmentations are acquiring the majority of energy subsidies in Egypt as represented in Table 5.

Table 5. Benefits Achieved by Several Income Groups in the Egyptian Society from Energy Subsidies during the Fiscal Year 2004/2005

\begin{tabular}{|c|c|c|}
\hline Income Segmentations & $\begin{array}{c}\text { Average Household's } \\
\text { Share of Subsidies in EGP }\end{array}$ & $\begin{array}{c}\text { Percentage of Total } \\
\text { Population in Egypt }\end{array}$ \\
\hline $\begin{array}{c}\text { The Lowest Income } \\
\text { Segmentation }\end{array}$ & 234 & $20 \%$ \\
\hline The Second Segmentation & 314 & $20 \%$ \\
\hline The Third Segmentation & 551 & $20 \%$ \\
\hline The Fourth Segmentation & 640 & $20 \%$ \\
\hline $\begin{array}{c}\text { The Fifth Segmentation (The } \\
\text { Highest Income Group A) }\end{array}$ & 873 & $2 \%$ \\
\hline $\begin{array}{c}\text { The Fifth Segmentation (The } \\
\text { Highest Income Group B) }\end{array}$ & 1789 & $2 \%$ \\
\hline
\end{tabular}

Source: The Egyptian Parliament, Budget and Plan Committee, Additional Subsidies for Petroleum Products Report, 2008.

It seems that energy subsidies distribution is highly distorted and biased towards the richest income segmentations in the Egyptian society. The highest 2 percent income class is acquiring 1789 LE while the lowest income class, the poorest 20 percent in the Egyptian society, is acquiring only $234 \mathrm{LE}$.

In addition, the Egyptian economy has been suffering from monopolistic practices in several fields of the economy. Monopolists increase the intense of poverty in Egypt through the continued and accelerated rise of overall price level causing high rates of persistent inflation.

\section{CONCLUSION}

The analysis which has been explained in this paper states that the trickle-down economics is not valid in Egypt. When poverty rates decline in the Egyptian economy, it is attributed to government interventions to reduce poverty. In Egypt, economic growth is biased to the richest segmentations in the Egyptian society. We can call that the economic growth in Egypt 
during the last 30 years was pro-poor growth. Therefore, it is not wise to say that higher economic growth would always cause poverty reduction. Capital formation has a significant positive impact on poverty reduction in the Egyptian economy. However, during the last 30 years capital formation as percentage of GDP has been declining gradually which help increase poverty rate. The study recommends that the Egyptian government increase labor-intensive projects instead of depending on infrastructure and mega projects that are capital-intensive. In addition, it is recommended that the Egyptian government continue subsidies reform through liberalizing the energy products prices and targeting the poor with income transfer programs. Moreover, to combat poverty in Egypt, the government must destroy monopolistic practices through increasing competition in markets and punish the monopolists. Also, it is recommended to redirect the saved resources from subsidies reform towards spending on education and health care. More public spending on education and health care means increasing capital formation as percentage of GDP and higher investment levels on Egyptian human capital. Of course, this will have positive impact on alleviating poverty in the Egyptian society. More investments in Egyptian human capital will enable the poor Egyptians to get jobs, either inside or outside Egypt, and earn higher income which enable them to escape from poverty circle. Finally, it is better for the Egyptian government to replace its philosophy of trickle-down economics by the philosophy of from bottom-up economic development framework.

\section{References}

Balisacan, A. M., Pernia, E. M. and Asra, A., Revisiting growth and poverty reduction in Indonesia: what do substantial data show? Bulletin of Indonesian Economic Studies, 2003. vol. 39, 329-151.

Banerjee, A., Dolado, J. J., Hendry, D. F. and G. W. Smith, Exploring Equilibrium Relationships in Econometrics through Static Models: Some Monte Carlo Evidence. Oxford Bulletin of Economics and Statistics, 1986. 48 (3), $253-$ 277.

Charemza, W. W. and D. F. Deadman, New Directions in Econometric Practice: General to Specific Modelling, Cointegration and Vector Auto-regression. Aldershot: Edward Elgar Publishing Limited, 1992.

Deaton, A., Counting the world's poor: problems and possible solutions. World Bank Research Observer, 2001. vol. $16,125-47$.

Dickey, D. A. and W. A. Fuller, Distributions of the Estimators for Autoregressive Time Series with a Unit Root. Journal of the American Statistical Association, 1979. 74 (3), 427-431.

Dickey, D. A. and W. A. Fuller, Likelihood Ratio Statistics for Autoregressive Time Series with a Unit Root. Econometrica, 1981. 49 (4), 1057-1072.

Dickey, D. A., Jansen, D. W. and D. L. Thornton, A Primer on Co-integration with an Application to Money and Income. Federal Reserve Bank of St. Louis Review, 1991. 73 (2), 58-78.

Dolado, J. J., Jenkison, T. and S. Sosvilla-Rivero, Co-integration and Unit Roots. Journal of Economic Surveys, 1990.4 (1), 249-273.

Dollar, D. and Kraay, A. Growth is good for the poor. Journal of Economic Growth, 2002. vol. 7, 195-225.

Engle, R. F. and C. W. J. Granger, Co-Integration and Error Correction: Representation, Estimation and Testing. Econometrica, 1987. 55 (1), 251-276.

Fan, S., Hazell, P. and Thorat, S., Government spending, growth and poverty in rural India. American Journal of Agricultural Economics, 2000. vol. 82, 1038-51.

Fishlow, A., Inequality, poverty and growth: where do we stand? pp. 25-37 in Bruno, M. and Pleskovic, B. (eds), Annual World Bank Conference on Development Economics 1995, World Bank, Washington, DC.

Granger, C. W. J., Some recent developments in a concept of causality. Journal of Econometrics, 1988. vol. 39, pp. 199-211.

Handy, H., and A. Subramanian, The Egyptian Stabilization Experience. International Monetary Fund, Middle East Department, (Washington D.C.: IMF), 1997.

Haque, T. and Verma, S., Regional and class disparities in the flow of agricultural credit in India. Indian Journal of 
Agricultural Economics, 1988. 43(3).

Harriss-White, B., Destitution and the poverty of its politics—with special reference to South Asia. World Development, 2005. vol. 33, 881-91.

Holden, K. and J. Thompson, Co-Integration: An Introduction Survey. British Review of Economic Issues, 1992.14 (3), 1-53.

Johansen, S., Statistical analysis of cointegrating vectors. Journal of Economic Dynamics and Control, 1988. vol. 12, 231-54.

Mallick, S., Capital formation in Indian agriculture: recent trends. Indian Journal of Agricultural Economics, 1993. vol. 48, 667-77.

Mallick, S. and Basu, S., When Does Growth Trickle Down to the Poor? The Indian Case. Cambridge Journal of Economics, 2008. vol. 32, 461-477.

Marotta, D., Yemtsov, R., El-Laithy, H., Abou-Ali, H., Al-Shawarby, S., Was growth in Egypt between 2005 and 2008 pro-poor? The World Bank, 2011. WPS5589

Masih, A. and R. Masih, Macroeconomic Activity Dynamics and Granger Causality: New Evidence from a Small Developing Economy Based on a Vector Error-Correction Modelling Analysis. Economic Modelling, 1996. vol. 13, 407-426.

Mehta, A. K. and Shah, A., Chronic poverty in India: incidence, causes and policies. World Development, 2003. vol. 31, 491-511.

Perkins, D., Radelet, S., Lindauer, D., and Block, S., Economics of Development. Norton and Company Inc., New York, USA, 2012. Seventh Edition

Ravallion, M. and Datt, G., Why has economic growth been more pro-poor in some states of India than others? Journal of Development Economics, 2002. vol. 68, 381-400.

Thomas, R. L., Modern Econometrics: An Introduction. Essex: Addison Wesley Longman Limited, 1997. 